\title{
Um outro herói modernista
}

Marco Aurélio Coelho de Paiva

0 contraste entre os modos diferenciados de delineamento dos heróis do romance/rapsódia M acunaíma, de M ário de Andrade, e do romance social Terra deicamiaba, deAbguar Bastos, publicados, respectivamente, em 1928 e 1931, em muito revela a especificidade e o tipo de dinâmica a marcar e determinar as múltiplas relações entre autores e obras culturais dentro desse "mundo social" relativamente autônomo que éo campo literário. Sea aversão de M ário deAndrade, por exemplo, a qualquer tipo de regionalismo em literatura ancorava-se na sua percepção de quase confinamento "de beco" a que determinados escritores contentavam-se em permanecer, o que, em última instância ea despeito da ânsia demonstrada por tais autores em deslindar uma realidade peculiar, redundaria, ao revés, em uma deturpação da própria realidade eda nacionalidade', Abguar Bastos, por seu turno, buscou contrapor-sea essa posição do autor de Paulicéia desvairada ao tentar reconciliar na sua prosa ficcional de estréia uma perspectiva modernista e uma visão regionalista da Amazônia.

Somente 0 entendimento, portanto, dessa sociologia singular a presidir o processo de criação artística eliterária pode nos fazer melhor dimensionar o tipo de articulação a ser estabelecida entre uma obra cultural e o seu tecido social próprio. Conforme salienta Bourdieu (1996b), uma sociologia pertinente das obras culturais não pode sucumbir às facilidades e aos enganos de uma abordagem com pretensões de estabelecer relações diretas

1. "Regionalismo émate aqui, borracha ali [...] pobreza sem humildade [...] cai pirismo esaudosismo, comadrismo que não sai do beco e, o queé pior, se contenta com o beco. [...] Re gionalismo, esse não adianta nada nem para a consciência da nacionalidade. Antes a conspurca e depaupera-lhe estreitando por demais o campo da manifestação e, por isso, a realidade. 0 regionalismo é uma pragaantinacional. T ão praga como imitar a música italiana ou ser influenciado pelo estilo português" (M ário de Andrade apud Leite, 1994, p. 669). 
entre o plano simbólico das obras e, por exemplo, o conjunto das demandas políticas e ideológicas dos diferentes grupos sociais. D a mesma forma, também não éviável ater-se aos diferentes bens simbólicose culturais como se eles estivessem completamente apartados de uma série de ingerências de ordem social que, de um modo ou de outro, tendem a interferir no processo defatura das obras. Entendemos, nesse sentido, queo aparato conceitual formulado por Bourdieu quanto à apreensão das obras culturais, e da obra literária em particular, nutre-se e supera toda uma tradição de discussão acerca do relacionamento entre, por exemplo, a crítica literária e uma sociologia da literatura (cf. Jurt, 2004, p. 51).

O ra, embora o contexto histórico-social da conjuntura brasileira do período compreendido entre os anos finais da década de 1920 e o início dos anos de 1930 estivesse passando por um processo de conturbação política e cultural (cf. Candido, 2000a) (fato que, por seu turno, não pode ser desconsiderado por qualquer análise sociológica, além de converter-se em fator decisivo no processo de constituição das próprias regras de seleção e atuação no campo de produção simbólica ainda em estruturação), a interlocução entre Abguar Bastos e M ário de Andrade salta aos ol hos justamente quando atinamos para a combinação entre os ditames externos da conjuntura sociocultural e os aspectos internos a definir a fatura das obras ora em foco de ambos os autores. 0 modo de construção ea caracterização dos heróis nas respectivas narrativas, dessa forma, apontam para a necessidade de considerar, em combinação com aqueles fatores externos em ebulição, os aspectos mais internos a definir os entrechos das obras e, com isso, buscar aí os recursos analíticos indispensáveis para uma reflexão acerca das posições e das adesões estilísticas e políticas de um e de outro. É dessa forma que as questões referentes à nacionalidade e ao regionalismo surgem como eixos centrais do diálogo e das contraposições do escritor paraense diante do escritor paulista.

Com esse enfoque, Abguar Bastos destaca-se como um autor central de um "regionalismo" amazônico renovado, isto é, um autor a encarnar uma visão "de dentro" da Amazônia sem, no entanto, desatrelar-se das influências e dos vínculos das correntes modernistas que tão profundamente 0 marcaram em seu período de formação no contexto cultural da cidade de B elém. No quadro regional, Abguar Bastos e outros escritores e artistas amazônicos atuaram como divulgadores entusiasmados das novidades esté ticas propaladas a partir deSão Paulo. M as, ébom frisar, não setratou deum simples mimetismo no âmbito regional do que antes fora "encenado" e ex- 
perimentado por outros artistas e escritores nos centros culturais mais dinâmicos, onde, de certa forma, uma legitimação cultural ia se consolidando.

É conhecida a armação da rede de disseminação das idéias modernistas pelas diversas regiões do país ao longo da década de 1920, após o evento paulista². M esmo que um escritor como Joaquim Inojosa, por exemplo, tenha assumido no $\mathrm{N}$ orte e no $\mathrm{N}$ ordeste o papel de porta-voz e divulgador autorizado das novas idéias estéticas surgi das na "paulicéia", e isso a ponto de arvorar-se a mensurar 0 grau de adesão às novas idéias a partir de São Paulo (cf. Inojosa, 1975), é bom salientar que na Amazônia tais idéias, de alguma forma, já se faziam presentes nos pequenos círculos e cenáculos artísticos e intelectuais, com dicção e lideranças locai $s^{3}$. 0 poeta Bruno de M enezes, nesse sentido, é outro nome da Amazônia a ser destacado no bojo das inovações estéticas perseguidas; e isso não só por sua origem social e pela sua militância política anarquista, mas também pelo seu empenho consciente em produzir uma poesia livre das amarras do parnasianismo, apesar deainda preso, em um primeiro momento, ao simbolismo (cf. Figueiredo, 2001, p. 207).

Conforme demonstrado por Figueiredo (2001), os variados círculos literários regionais atingiram um grau de organização e certa consistência intelectual a ponto de criarem revistas literárias que, mesmo sob patrocínio oficial do poder público, tinham o objetivo de divulgar as novas idéias, abrindo, assim, um confronto direto com os representantes de um passadismo ainda reinante. Embora a pesquisa de Figueiredo restrinja-se ao ambiente intelectual de Belém, de onde o autor generaliza suas conclusões para a Amazônia como um todo, também seria possível identificar em $M$ anaus esse mesmo tipo de movimentação de uma intelectualidade "Iocal" em busca de um "ajuste" estético. N omes estreitamente associados ao evento modernista paulista, como os de M enotti del Picchia e Raul Bopp, por exemplo, faziam-se presentes nessas publicações então criadas não só como meios de disseminação do novo ideário, conforme quer fazer crer Figueiredo, mas também como um instrumento de diferenciação entre os "novos" e os "antigos". Revistas como Redenção e Equador, ambas editadas em $M$ anaus, e Belém N ova, editada na capital paraense, todas surgidas no período de meados e final da década de 1920, foram exemplos concretos, a um só tempo, de um empenho coletivo e de uma acirrada disputa intelectual por uma definição legítima da realidade regional amazônica4.

Com o desdobramento do movimento modernista da sua fase hegemonicamente "estética” para outra mais “ideológica” (cf. Lafetá, 2000), o tema
2.Para uma abordagem contestadoradessa visão hegemônica do modernismo brasileiro a partir do "modelito paulicéia", ver Velloso (1988, 1996).

3. A respeito das reverberações edas redefinições do "movimento modernista" naAmazônia, ver Figueiredo (2001).

4. No caso específico de Equador, revistaeditada em M anaus a partir de 1929, é possível identificar no seu texto de apresentação uma insatisfação dos escritores locaiscom osrumosentão tomados pelo modernismoem SãoPaulo. Assim escrevia Clovis Barbosa, o editor da re vista, jánaapresentação do primeiro número: "[...] Os antropófagos paulistas andam numa afoitezabrabadecomer tudo quanto é embromador que se veste no couro de onça dum sistema estético bárbaro, jovem só paradisfarçara sua educação clássica. E nós não podemos ficar acocorados sem um entusiasmo fecundo [...]" (grifos do autor). Ver Barbosa (2001, p. 5). Embora o editor da revista tente apontar os descaminhos trilhados 
pelos modernistas de São Paulo eidentifique osprováveismotivosde tal fato, ébom salientar que o conjunto variado dos autores reunidos nesse primeiro número deEquador não estava muito longe de uma educação igualmente clássica. As adesões ao modernismo não estavam em uma dependência direta da formação recebida, massim de umaatuação deruptura com vistasaganhossimbólicos futuros dentro deum quadro deredefinição do campo deprodução cultural. Sobreo redirecionamento dealguns autores paulistas deumaprodução literá riatradicional paraa estética modernista, ver M iceli (2004).

5. “[...] Bruno de M enezes começava por de finir o caráter coletivo do movimento nortista, baseado na soma de 'energias' que pudessem dar um sentido político e publicidade a um novo veículo de idéias - uma simples 'revista de arte e literatura'. Essa lembrança era ainda mais importante porque se estava falando de Amazônia, uma terra [...] que Bruno de Mene- do regionalismo não só ganhou realce etransformou-se em objeto de acirramento entreintel ectuais deregiões diversas do país, como no caso de G ilberto Freyre ao contestar, ainda em meados da década de 1920, o monopólio paulista acerca dos usos do termo "moderno" (cf. Freyre, 1967), mas também fez emergir diferenças e disputas internas a cada região. N o caso do círculo de intelectuais e artistas reunidos em torno da revista B elém N ova, por exemplo, isso fica evidenciado, conforme demonstra Figueiredo (2001), já nos diferentes "manifestos artísticoseliterários" então elaborados.

0 regionalismo apregoado por Bruno de $M$ enezes, por exemplo, contrastava com o de Abguar Bastos. Embora estivessem juntos no combate ao passadismo e ambos, de maneira engajada, fossem filiados aos movimentos vanguardistas da época, a idéia do regional ganhava conotação diversa em um e em outro. Se para Bruno de M enezes o regionalismo amazônico deveria ser pensado em conformidade com o que vinha ocorrendo nas demais regiões do país, especialmente no Sul ${ }^{5}$, para Abguar Bastos um "regionalismo amazônico" deveria ganhar contornos próprios e específicos, completamente dissociados, portanto, de possíveis outras influências regionais e nacionais ${ }^{6}$.

Esse desacordo entre Bruno de $M$ enezes e Abguar Bastos demonstra 0 que estava de fato em disputa, isto é, o modo de representar literariamente a Amazônia e, como decorrência, alçar a criação artística regional a um novo patamar e, ao mesmo tempo, investir de legitimidade novos agentes sociais ${ }^{7}$. A incorporação de novos elementos estéticos originários das vanguardas européias, mesmo que em parte filtrados e retraduzidos pelos modernistas paulistas, associou-se aos el ementos endógenos da região tão bem conhecidos pelos intelectuais locais. 0 primitivismo, por exemplo, tema fulcral das variadas vanguardas ${ }^{8}$, casava-se perfeitamente com o cenário selvagem do ambiente amazônico.

Para melhor identificar os meandros percorridos por um autor como Abguar Bastos na formulação de uma dada representação regional, portanto, faz-se necessário não só tomar contato com seus escritos iniciais, como, por exemplo, o manifesto Flaminaçu, de 1927, e o seu romance de estréia Terra de icamiaba, de 1931, mas também reunir a essas produções o contexto de acirramento intelectual e político que permeou a criação de tais obras, seja no plano local, seja no nacional.

Q uando sua posição como um "autor regional" conhecido e reconhecido localmente consolidou-se e, nesse sentido, o seu "manifesto aos intelectuais paraenses" converteu-se em um ato de afirmação dessa liderança, a 
publicação do seu primeiro romance, Terra de icamiaba, destinava-se claramente a contrapor-se ao arranjo estético contido no recém-publicado $\mathrm{M}$ acunaíma, de $M$ ário deAndrade, revelando, assim, as aproximações eas rupturas presentes tanto no modo de conceber a relação do regional com 0 nacional, como reforçar uma oposição entre um autor e outro no emaranhado de estratégias a dinamizar o campo literário naquele período. A posição de Abguar Bastos relativamente a outros "autores regionais", dessa forma, também obedecia a uma estratégia de aproximação e afastamento com escritores considerados os líderes do modernismo paulista, 0 swald de Andrade e $M$ ário de Andrade.

Abguar Bastos nasceu em Belém no dia 22 de novembro de 1902. Seus estudos primário e secundário foram realizados em sua cidade natal, até 1921, quando ingressou na Faculdade de $D$ ireito em $M$ anaus, bacharelando-se em 1925. Começou a trabal har como bancário em Belém e, depois, ocupou o posto de secretário da prefeitura da cidade de Coari, no interior do Amazonas; em seguida, assumiu interinamente o cargo de prefeito. Entre 1926 e 1928 exerceu o ofício de tabelião em um cartório, tornando-se logo depois, já em 1929, redator de debates da Assembléia Legislativa do estado do Amazonas. A atividadejornalística, por sua vez, marcou tanto 0 seu ingresso no "mundo das letras" como a sua inevitável inserção nos pequenos círculos intelectuais de $M$ anaus e de Belém. Seu auto-retrato de juventude, então delineado com fortes traços de misticismo, anos depois, quando do seu depoimento ao inquérito literário de Edgard Cavalheiro, refletia, na realidade, as incertezas quanto à validade das diferentes correntes literárias e artísticas existentes no âmbito da realidade provinciana.

Comecei místico como todo menino de província. Era supersticioso e tinha um bruto medo do futuro. 0 "amanhã" preocupava-me até a fadiga. A tormentava-me, por exemplo, até doer a cabeça, o que seria isso de ser "eterno" eisso de ser "infinito". M eu cérebro se perdia nessa tormentosa viagem e dela eu regressava geralmente perplexo e abalado [...]

Q uando me senti vacilante procurei apoio. Freqüentei a igreja dos católicos, dos batistas e dos espiritistas. Bati uma vez às portas de um templo teosófico. Fui ao Círculo Esotérico da Comunhão do Pensamento. Andei nas ladainhas dos negros. Rondei os batuques de Santa Bárbara. Em tudo eu encontrava um ar esquisito de contrição forçada e via sempre o interesse profano ligado ao cenário litúrgico. $0 \mathrm{~s}$ sacerdotes, os guias, pareciam fracos evulgares, sem força capaz de deter o rebanho que oscilava entre as práticas variadas da religião. N ão compreendia sobretudo essa zes acreditava ser 0 eterno cenário da luta entrea naturezaeacultura, o ambiente e seu hóspede mais importante [...]". "Bruno de M enezes estava convicto [de] quetinha muito a aprender com a experiência dos estados do Sul, ondejáera 'flagrante o domínio de uma forte correnteintelectual, semeadora do bom gosto estético'. Já havia por lá um 'natural e louvável orgulho em valorizar as publicações regionais', o que tanto se perseguia nas redações paraenses. A grande dificuldade, apontava Bruno, estava na mentalidade de publicistas e consumidores da terra que ainda optavam pelos matutinos elibretos, unicamentepor 'um princípio de boa e fácil digestão' [...]". Ver Figueiredo (2001, pp. 236-237).

6. "Confrontando aversão deBruno deM ene zes em U ma reação ne cessária, Abguar Bastos lançara, na mesma edição de Belém N ova, outro manifesto questionando a preeminência sulistaanteas outras regiões do Brasil. À geraçãoquesurgepossuíaum 
texto bem maiscontundentequeosmanifestos anteriores, escrito na forma de um libelo aos jovens da terra. 'É che gada parao N ortebrasileiroahoraextraordiná riadeseu levantamento. Ergamo-nos!.' As palavras iniciaisjá davam o tom do manifesto. A idéiaerainverter o rumo dascoisas, transformandoo Paráno'baluarteda liberdade nortista'. A justificativa parecia óbvia, poiso 'sul', queixava-se Abguar, 'propositadamente, se esquece denós'. Por isso o manifesto". Ver Figueiredo (2001, p. 240).

7. Sobrea relação entre a formulação de uma dada representação da idéia de região e a mobilização de agentessociaislegítimos, ver Bourdieu (1989).

8. Acerca do "primitivismo" como temática de fundo dos diversos movimentos de vanguarda artística do começo do século $X X$, ver N unes(1979) eAmaral (1997).

9.D ados biográficos extraídos de Beloch e Abreu (1984) e M enezes (1978). disputa de Partidos religiosos em torno de um Chefe comum, indivisível e eterno: D eus. Às vezes pensava que o velho conceito de dividir para reinar já era coisa velha entre os Anjos das doze igrejas da Ásia.

Finalmente, fiquei como pára-quedista que vai caindo no meio de inimigos ocultos. E até cheguei a acreditar em N ietzsche (C avalheiro, 1944, p. 17).

Q uando desse seu depoimento, no início da década de 1940, Abguar Bastos já desfrutava a posição de um autor de referência de uma literatura nortista, uma espécie de expressão legítima e legitimada de uma literatura amazônica. Sua carreira literária já havia, inclusive, desdobrado-se em uma carreira política. Sua participação efetiva na R evolução de 1930 propiciou uma aproximação com os grupos políticos vitoriosos do movimento. Tornou-se, por conta disso, assessor direto do então interventor no estado do Pará e parlamentar nos anos imediatamente correntes. M as, em função do seu engajamento político na Aliança N acional Libertadora, a eclosão do Estado N ovo em 1937 encurtou o seu mandato de deputado federal, e ele exerceu essa sua primeira experiência parlamentar somente de 1935 a 1936.

Como escritor relativamente reconhecido, a rememoração dos caminhos então possíveis de sua trajetória pôde ser vislumbrada, aí nesse breve relato, por meio de uma perspectiva distanciada e em conformidade com a própria posição por ele já assumida no campo literário. Portanto, a reconstrução das suas preocupações intelectuais de juventude, quando ainda atuante no âmbito regional, ganhou essa versão quase sublimada de misticismo e religiosidade. $\mathrm{N}$ ão é difícil identificar uma tentativa de arrefecer as polêmicas intelectuais e artísticas das quais participou quando demonstra, no depoimento, certa inquietação e incompreensão com relação à disputa espiritual em torno de "partidos religiosos". D e fato, essa referência a reali idades místicas e religiosas acaba convertendo-se em uma maneira bastante singular de expressar e perceber como "desencarnados" os embates literários.

M as o próprio significado do movimento modernista e o modo pelo qual ele se instaurou no contexto amazônico foram reconstruídos por Abguar Bastos como um desdobramento necessário de outras correntes intelectuais e literárias presentes no período de sua formação intel ectual.

N a minha província a transição entre o parnasianismo e o "modernismo" se processou através do simbolismo. Colocávamos nossa féem el ementos de outras plagas: 
Eugênio de C astro, Cesário Verde, M ário de Sá C arneiro. 0 simbolismo entre nós era muito rico de lirismo e não tinha a força, por assim dizer, impressionista da poesia portuguesa.

0 simbolismo, a meu ver, foi a etapa que serviu para triturar os restos parnasianos e românticos e preparou o terreno que mais tarde recebeu o "modernismo".

E qual a significação do "modernismo" para a mentalidade nacional que procurava rumos ao meio da confusão universal decorrente da grande guerra?

0 "modernismo" era uma justaposição das correntes ou escolas literárias que irrompiam freneticamente na Europa. Era um fenômeno da inquietação mundial que procurava naturalizar-se brasileiro para gozar de determinados privilégios.

$\mathrm{N}$ ascia dentre calamidades econômicas e morais que solicitavam reformas em todos os quadrantes das atividades práticas (I dem, p. 18).

Esse clima de inquietação intelectual reinante no começo do século XX, e que então assolava não só a Europa e os principais centros culturais do Brasil, mas também se refletia na Amazônia, transformava a poesia simbolista em uma primeira opção de demonstração de desagrado por parte de jovens literatos com tudo o que estava ainda consolidado em termos deliteratura. $M$ as, dadas a necessidade de agir demaneira mais contundentediante das "calamidades econômicas" e as possibilidades de renovação de todas as "atividades práticas", prevaleceu a atitude de reformar e remodelar tudo. E como prova desse clima de mudança a incitar rebeliões, o próprio Abguar Bastos reproduz em seu depoimento a Edgard Caval heiro uma carta a ele endereçada de outro autor também participante daquele ambiente: Raul Bopp.

[...] Nós precisamos, é como eu escrevi há tempos, recrutar os fatores postos à margem, forças escondidas e mal aplicadas. D emolir a velha sensibilidade (do bacharel, do literato fofo e palavroso). Tomar o pulso da terra. Consultar a floresta. Você aí agite essa Amazônia em combinação com o pessoal do Pará. H ostilmente. Intolerantemente. $\mathrm{N}$ ão se pode fazer uma cruzada amena. D errubada grande. Enforque o pessoal a cipó [...] (Idem, p. 20).

0 tom desse trecho da carta de Raul Bopp não deixa dúvida quanto às angústias que acometiam os jovens literatos da Amazônia durante a década de 1920. O stais "fatores postos à margem" pela literatura vigente, e ainda comandada por uma "sensibilidade envelhecida", precisavam ser resgatados. U ma literatura nova que retomasse os elementos nativos da Amazô- 
nia como motivos principais de criação literária passou a ser uma espécie de mote a guiar os novatos. U ma afinidade e aproximação literária, portanto, entre esse grupo de jovens intelectuais amazônicos e as figuras de 0 swald e $M$ ário de Andrade eram inevitáveis. 0 próprio Abguar Bastos reconhecia isso no momento que listou as influências mais marcantes naquele período:

0 gesto de Graça Aranha, brigando com a Academia, valeu para nós como um sinal atrevido de marcha.

Fomos deixando de lado Augusto dos Anjos, Cruz e Sousa, O legário... Elegíamos novosnomesno altar da consagração: Guilherme deAlmeida, Bopp, Ronald, Felipe de O liveira, Tarsila, Cecília M eireles, M ário de Andrade, Álvaro M oreira, D rummond, Ascenso, 0 swald...

M as na minha terra, além de Graça Aranha ede Bopp, a influência crescia mais no rumo de $M$ ário e 0 swald de Andrade.

M ário por via de seus sensacionais estudos sobre a arte moderna e de sua farta contribuição ao movimento. 0 swald por ter lançado o primeiro romance absurdo do modernismo: Trilogia ao exílio. Ainda guardo os debates feridos em minha terra em torno desse livro [...] (Idem, p. 21).

Se M ário de Andrade merecia alguma admiração por parte do autor de Terra deicamiaba, isso ocorria demaneira maistímida eem função da novidade representada por Paulicéia desvairada. Já quanto às influências de 0 swald deAndrade sobrea obra deA bguar Bastos, deveser destacado aqui 0 profundo impacto causado no autor paraense pelo "programa" reformador daartee daliteratura nacional contido no M anifesto pau-brasil, de1924. Foi 0 swald a figura que mais impressão lhe causou naquele momento, sendo atémesmo o motivo de divergências com seu "confrade" Bruno de M enezes (cf. Sena, 2002, p. 9). D aí a referência aos "debates feridos" em seu depoimento aEdgard $C$ avalheiro.

E foi sob esse impacto do M anifesto pau-brasil que o próprio Abguar Bastos, em 1927, publicou na revista Belém N ova uma espécie de "versão amazônica" do "programa oswaldiano": o Flaminaçu, que em tupi (flamin'-assú, pela grafia original) significa "grande chama". Sua pretensão com esse manifesto era não só combater os representantes do passadismo literário da região, mas também convocar os intelectuais paraenses para o movimento renovador iniciado em São Paulo eque na Amazônia deveria ganhar feições próprias, dadas as peculiaridades da própria natureza. 
ouvi:

Primeiramente vós, poetas e prosadores divinos da minha geração; depois de vós, prosadores e poetas, apajelados à sombra das vossas tabas primitivas e que estais a ver, espetados em paus sagrados, os despojos, as glórias, as caveiras - das vossas escal adas às cordilheiras da ilusão. Àqueles a minha voz vai confinada. A estes ela se intimida. Àqueles ela se recolhe como um zangão à sua colméia. A estes ela recal citra. $\mathrm{N}$ ão que os receie no choque, mas, de fato, porque eles não procurarão, sem esforços dolorosos, metêlas em suas sacolas de Arte.

Assunto-vos agora o meu propósito de uma corrente de pensamento, cara a cara à que se inicia no sul com esta pele genuína: "Pau-brasil" (Bastos, apud Jornal da U nião Brasileira de Escritores, 2002, p. 9)

Foi a partir desse manifesto, endereçado não só aos jovens literatos interessados em encampar os novos princípios estéticos e políticos abertos pelo movimento modernista, mas também destinado a combater todos os representantes de uma literatura passadista, que o próprio Abguar Bastos se viu forçado a produzir um romance em conformidade com o programa então esboçado.

[...] E desde esse momento eu esbocei o meu primeiro romance dentro do programa literário a que me filiara. Foi esse Amazônia que ninguém sabe que depois foi editado no Rio com outro título: Terra deicamiaba. Esselivro, sendo um romance, era também uma plataforma.

Porém o quenão se evitava éque o movimento literário iniciado em 22 setransformasse em movimento político (Cavalheiro, 1944, p. 22).

Essa incompreensão quanto aos desdobramentos políticos de um movimento que se iniciou motivado por transformações estéticas estava na base da distinção que o próprio Abguar Bastos fazia entre "nacionalismo" e "brasilidade". E é justamente essa diferenciação entre uma coisa e outra que, a um só tempo, expressava o seu pensamento, ainda amarrado a um ranço evolucionista, e a sua contestação e contraposição a M ário de Andrade quando da publicação de M acunaíma em 1928. Seu pensamento evolucionista, por exemplo, já aparecia no texto do artigo/manifesto Flaminaçu quando, ao explicitar os objetivos almejados naquela "convocação", tentava manter o programa em aberto para futuras adaptações, mas referindo-se a estas como "transformações evolutivas". N a nota introdutória à edição do livro de Craveiro Costa, A conquista do deserto ocidental, de 1940, Abguar 
10. “[...] Flam In AÇu não éum estorvo aos grandes charivaris da civilização. N ão! Ela admite as transformações evolutivas. 0 seu fim especialíssimo eintransigenteédar um calço delegenda à grandeza natural do Brasil, do seu povo, das suas possibilidades, da suahistória." Ver Bastos (1937) e também a introdução deAbguar Bastosao livro de Craveiro Costa (1940, pp. 7-59).
Bastos também associava ao seu materialismo os ranços de um pensamento evolucionista. N esse sentido, ele entendia os mitos e as lendas amazônicos como desdobramentos diretos dos modos e meios de produção que ciclicamente assolavam a região ${ }^{10}$. Já as suas restrições quanto ao "herói sátiro", e então "mitificado" por M ário de Andrade em seu livro, ancoravam-se na confusão instaurada, segundo ele, pelo próprio desdobramento do modernismo quando confundiu o "todo nacional" com uma "síntese brasileira". Em seu depoimento a Edgard C aval heiro essa diferenciação foi longamente esmiuçada:

Porque uma coisa era o "nacionalismo", o todo "nacional", e outra era a "brasilidade", a síntese "brasileira".

$\mathrm{N}$ ão sei se houve quem estudasse esta questão. Só sei que da confusão resultou um como que desmoronamento do edifício.

O fastio por não se poder agarrar um herói levou M ário de Andrade à sátira do M acunaíma, ímpar no gênero.

Então, que éque sucedia? 0 nacionalismo se convertia em pasta colorida na superfície do problema. Através da síntese do herói nacional que virava mito e por isso mesmo servia de eixo apenas para a literatura simbólica e sumamente abstrata, determinados grupos se deixaram exaltar pela simbologia exagerada, em torno não do que havia de vivo na humanidade brasileira, mas justamente à roda do que sobrava em abstração e mito.

0 "verde-amarelismo" não teve outra intenção.

0 movimento "pau-brasil" era mais sincero, ainda que nascesse singelamente pictórico. M as o pau-brasil era brasilidade porque procurava resolver os problemas da terra.

A diferença entre nacionalismo e brasilidade é que o primeiro era subjetivista e a segunda objetivista. U m se apoiava na psicologia das massas, outra na ação delas. O nacionalismo modernista cheirava a bacharelismo do império.

A brasilidade perdia a pose do bacharel, do sujeito que era brasileiro mas pensava em latim. A brasilidade não se acanhava de andar de pé no chão atrás de mato, índio, macumba, tajá, minhocão, uirapuru.

0 nacionalismo insistia no erro de querer imprimir um caráter de programa às nossas coisas. A brasilidade queria a sensibilidade pura, a índole, o Brasil em si. 0 nacionalismo queria estratificar a consciência nacional brasileira com todas as camadas falsas nela contidas. $\mathrm{N}$ ão queria raspar a crosta pernóstica advinda de influências que bloqueavam, há mais de um século, a verdadeira sensibilidade nacional. 
A brasilidade, quando se refugiava nas nossas mais esquisitas tradições, não estava retrogradando, estava protestando com a prata da casa na mão. Estava querendo consciência sem crosta, desespartilhada, barriguda mas honesta.

0 nacionalismo era aquele, como dizia Raul Bopp, que se envergonhava do jacaré. $\mathrm{N}$ ão queria que a gente pintasse nossos dramas de luta pela vida, que se falasse da tragédia da seringa, do cacau, da cana-de-açúcar, do al godão e da castanha, em seus terrores mais chegados ao brutal labor do nosso homem.

$\mathrm{N}$ ão queria, porque isso era falar mal do Brasil! D e maneira que o brasileiro havia de solucionar os seus problemas sem conhecer a realidade deles! (I dem, pp. 23-24).

Era essa concepção de "brasilidade", portanto, que, conforme Abguar Bastos, deveria nortear a criação artística e literária de todos aqueles interessados e envolvidos na resolução prática dos problemas relacionados com a realidadenacional do momento. A busca por um diagnóstico mais realista e acertado das inúmeras mazelas sociais do país, nesse sentido, fazia-se necessária, ea artee a literatura constituíam-seem instâncias primordiaisparaum engajamento nessa tarefa. Algo muito diverso, como é fácil notar, da concepção corrente de "nacionalismo", que, preocupada simplesmente em erigir símbolos a expressar a "psi cologia das massas", negligenciava aquele aspecto mais pragmático.

E foi justamente a partir dessa diferenciação e confrontação entre uma corrente e outra, tão bem detalhada algum tempo depois (conforme seu depoimento a Edgard ( avalheiro), que Abguar Bastos escreveu o seu primeiro romance em 1931: A Amazônia que ninguém sabe, cuja segunda edição, em 1934, teve o título alterado para Terra deicamiaba. 0 dado fundamental a ser ressaltado nessa narrativa éo delineamento do "herói regional" da trama, em tudo divergente do "herói nacional" forjado por M ário de Andrade ${ }^{11}$. Se M acunaíma, paradoxalmente, tinha como principal característica a ausência completa de "caráter", entendido esse termo não no sentido estritamentemoral, mas no sentido de não possuir uma "forma definitiva" e estável (daí as suas mudançase andanças um tanto quanto desordenadas ao longo da narrativa), Bepe, o herói de Terra de icamiaba, é dotado, inversamente, de um "caráter" fixo e rígido.

Em todas as regiões há um indivíduo que se destaca. É o gênio do lugar.

O de Badajós é o altaneiro, compacto e brônzeo.

$\mathrm{N}$ ovo e possante Aniaoba, desafia, com o peito nu, a valentia das raças. Chama-se Bepe.
11. Abguar Bastosprosseguiu ainda em seus ataques a M ário de Andradequando da publicação de seu romance Safra, em 1937. Em umadaspassagensdesse romance, o narrador faz uma referência um tanto quanto jocosa ao autor dePaulicéia desvairada, quando o descreve de maneira pejorativa como um mero secretário da Rainha do C afé, dona Olívia Guedes Penteado. M asem contradição com esse papel de subalterno, o poeta M ário d'Almada (referênciadiretaao nomede M ário de Andrade) de monstra certa inquietação edecepção ao perce ber queoshabitantesda pequenavilaamazônica o desconhecem comple tamente. Ver Bastos (1937, pp. 179-180). 
Conhece o lago e os seus arredores. C onhece-os, dentro do meio-dia, com os olhos profundos, ou, de tato, dentro da treva. $\mathrm{N}$ em um fenômeno mesológico ou milagre geogênico lhe surpreende as décadas itinerantes. 0 s seus instintos adivinham as metamorfoses do tempo, matematicamente, como os sábios. Adivinham as chuvas, os ventos, os rumos, as cheias.

$\mathrm{N}$ as frentes difíceis o gênio de Badajós não muda.

Q uando diz: eu vou e volto, volta mesmo.

0 trabalho é a disciplina da sua força e a esperança disciplina-Ihe o coração [...] (Bastos, 1997, p. 2).

Embora também combata os poderosos e estrangeiros, Bepe alia-se claramente aos estratos sociais rebaixados eoprimidos da Amazônia, em atitude divergente, portanto, do herói pícaro de M ário de Andrade. Enquanto M acunaíma sai das brenhas da floresta e ruma em direção à cidade de São Paulo com o propósito de recuperar a "muiraquitã" das icamiabas, que então fora apropriada pelo gigante Piaimã (o peruano regatão/italiano industrial Venceslau Pietro Pietra), Bepe faz um percurso inverso, quando deixa a cidade de Belém com seus modismos eopta por habitar nos recônditos da selva. Lá ele lidera um punhado de caboclos, índios, negros e migrantes nordestinos em uma rebelião contra os estrangeiros e poderosos da região, efunda, utopicamente, ao final do romance, após peregrinar pela selva em busca da "terra das icamiabas", uma sociedade assentada na ausência de desigualdades sociais e da exploração de uns sobre os outros. Caminhos inversos, propostas divergentes e delineamentos opostos entre ambos os heróis que em muito indicam os intentos de Abguar Bastos diante da corrente de nacionalidade incrustada na simbologia de M acunaíma.

Segundo W ilson M artins, M ário deAndradehavia falhado no propósito deformular um romance com uma temática de revolução social. M as o ambiente político das vésperas da Revolução de 1930, ainda segundo o crítico, já incitava outros autores a empenhar-se nessa tarefa. Abguar Bastos teria sido um desses autores:

Amazônia que ninguém sabe, no qual Bepe figura como porta-voz do autor, é o $\mathrm{M}$ acunaíma que poderia ter sido ou o que $\mathrm{M}$ acunaíma desejaria ter sido, se imaginarmos que o projeto de $\mathrm{M}$ ário de Andrade era tomar o material folclórico como metáfora de uma situação social. Romancemodernista exemplar, o livro de Abguar Bastos responde com extraordinário automatismo ao que a sua geração obscuramente se havia proposto como "programa de romance", cujo primeiro modelo 
tinha sido 0 estrangei ro, logo modificado pela Bagaceira [...] (M artins, 1978, pp. 466-467).

Como éfácil notar, não é pouco o papel atribuído ao autor paraense em função da sua obra de estréia.

Contudo, e apesar de tudo, o livro de Abguar Bastos parecia abrir a série do "romance amazônico", assim como o de José Américo de Almeida lançara as fundações do futuro "romance nordestino" (ambos estavam no destino teórico e programático do M odernismo). Pode-se pensar que o prestígio de Mário de Andrade, deslocando para uma obra mal ograda como M acunaíma (enquanto romance) 0 interesse que idealmente teria cabido ao Amazônia que ninguém sabe (título horrendo, que terá certamente afugentado incontáveis leitores), frustrou o desenvolvimento de uma linha de ficção cuja "casa” já estava assinalada no quadro imaginário do gênero (I dem, p. 467).

Como prova desse caráter inaugural de um gênero, o autor de Terra de icamiaba, logo no pórtico do seu romance, explicita seus objetivos na elaboração daquela narrativa, insinuando de maneira clara o tipo de relação a ser estabelecido entre a realidade e a sua respectiva expressão simbólica, então devidamente ajustada:

Fiz um livro na Amazônia. Ajustei os símbolos à realidade. Procurei o homem na paisagem da vida, mas fixei a vida no panorama da terra. Andei, vi, perscrutei. [...] As histórias estão tatuadas nas gentes, talhadas nas pedras, calcadas nas árvores, delineadas na terra, submersas nas águas. Todos podem lê-las convenientemente. É questão de querer descer ao chão e escutar, com amor, os corações subterrâneos [...] (Bastos, 1997, p. iii).

Sendo a Amazônia tradicionalmente representada como uma região envolta por uma aura de mistérios e mitos, os intentos e as pretensões de Abguar Bastos estavam focados em "desvelar" o substrato social a engendrar e dar corpo a essa variedade de legendas e mitificações. N ote-se, no entanto, que, apesar de lançar mão do fabulário e das mitologias disseminadas pela região na composição da narrativa, o seu modo de entender a sociedade amazônica ancorava-se em certa prioridade conferida ao aspecto econômico como instância de explicação válida, ganhando primazia, portanto, ante qualquer outra esfera ou dimensão da realidade social. Assim 
procedendo, eleacreditava conferir um diagnóstico mais consistenteao todo regional. Seu projeto literário, nesse sentido, de fato não estava afastado da fatura daquilo que viria a ser o "grosso" dos romances sociais surgidos ao longo da década de 1930.

Embora esse seu primeiro trabalho literário de fôlego ainda pudesse ser aproximado das resoluções estéticas propagadas pelo primeiro modernismo, o que chama a atenção da sua narrativa, entretanto, é a preocupação com o "solo social" da região. 0 próprio nome do herói do romance, Bepe, foi resgatado por Abguar Bastos da mitologia dos índios tarianos, habitantes do alto rio N egro, sem sofrer, no entanto, qualquer descaracterização quanto ao seu perfil no âmbito da criação romanesca. Sabemos, nesse sentido, que o mito de M akunaima (com "k") foi alterado substancialmente por M ário de Andrade quando, aproveitando-se dos relatos mitológicos dos índios taulipáng e arecuná da região de Roraima, e então compilados pelo alemão Koch-Grünberg no início da década de 1910, moldou-os em um formato picaresco em seu romance (cf. Kothe, 2004, p. 159). No caso do romance do autor paraense, a figura mítica é transplantada integralmente para a composição do personagem.

Essa opção pela preservação das características do mito no interior da armação romanesca já era uma indicação clara da não-sati sfação de Abguar Bastos com uma abordagem da realidade brasileira aos moldes de M ário de Andrade em M acunaíma. Como sabido, a sociedade nacional de finais da década de 1920, então apresentando sinais evidentes de modernização, era representada literariamente pelo autor paulista por meio de um enfoque nativista, no qual um mosaico de lendas, mitos e ditos populares juntava-se no feitio de uma rapsódia a compor um todo inusitado e expressivo de uma nacionalidade brasileira já existente (cf. Sousa, 1979). A não-definição do herói do romance e o seu caráter mutável, por seu turno, apontavam para esse aspecto ainda disforme a expressar um amálgama de raças (cf. Ribeiro, 1993).

M acunaíma passou então uma semana sem comer nem brincar só maquinando nas brigas sem vitória dos filhos da mandioca com a $M$ áquina. $A M$ áquina era que matava os homens porém os homens é que mandavam na $M$ áquina... C onstatou pasmo que os filhos da mandioca eram donos sem mistério e sem força da máquina sem mistério sem querer sem fastio, incapaz de explicar as infelicidades por si. Estava nostál gico assim. Até que uma noite, suspenso no terraço dum arranha-céu com os manos, M acunaíma concluiu: 
- O s filhos da mandioca não ganham da máquina nem ela ganha deles nesta luta. Há empate.

$\mathrm{N}$ ão concluiu mais nada porqueinda não estava acostumado com discursos porém pal pitava pra ele muito embrulhadamente muito! que a máquina devia de ser um deus de que os homens não eram verdadeiramente donos só porque não tinham feito dela uma lara explicável mas apenas uma realidade do mundo [...] (Andrade, 1997, p. 31) 12 .

M as, de fato, o desagrado por parte do autor paraense em relação à obra de M ário de Andrade, conforme já salientado, residia no excesso de simbolismo e na "palidez" da realidade. Embora reconhecesse a importância e o papel das máquinas como um dado característico do "mundo moderno", com todos os seus respectivos desdobramentos econômicos e culturais, Abguar Bastos também considerava esse aspecto fundamental para uma compreensão moderna da Amazônia, mesmo que em seu romance um retorno à natureza fosse insinuado. M as esse retorno ocorria em função, justamente, da necessi dade de consi derar a especificidade da natureza amazônica como uma instância primordial no entendimento da realidade social da região. É assim que o narrador, de maneira um tanto quanto al egórica, explicita essa valorização da natureza diante de artefatos culturais modernos quando, no início do entrecho da trama, descreve a casa onde Bepe reside no interior da floresta.

Bepe não mora sozinho.

Tem um amigo: o cão.

Tem um bobo: o macaco sabido, que monta no cão.

Tem um adulador: o papagaio, que canta para o cão, porque o cão éforte e dorme embaixo da gaiola. 0 papagaio fica mudo para o macaco, porque o macaco sabido pode aprender a falar.

$\mathrm{N}$ a sala de Bepe o gramofone, também, como os bichos, mostra as suas habilidades.

Papagaio se fizesse papel de gente seria duas coisas: político e professor de lógica. O homem, deus dos bichos, aparou o prestígio do papagaio: inventou o fonógrafo. Papagaio pensou: se ensinasse o macaco a falar matava o fonógrafo.

Pensou de novo: sea voz do macaco acabasse com o fonógrafo quem ia para a sala era o macaco.

0 ra, antes ficar assim. M acaco não vai à sala. Por isto não pode aprender com 0 fonógrafo e fica, sempre, no quintal.
12. Acerca da "disformidade" de M acunaíma, ver Bastide (1983). 
Papagaio não morre de desgosto. Acredita que tem uma vantagem sobre o seu concorrente: não precisa de corda, nem disco. Tem, para isto, a chuva e a voz do dono (Bastos, 1997, pp. 5-6).

Apesar de ser produto da engenhosidade do homem, o fonógrafo é equiparado aos demais bichos na convivên cia com Bepe em sua casa. Embora, inicialmente, o prestígio do papagaio tenha sido diminuído pelo som produzido pela máquina, a natureza ainda era detentora de largas vantagens diante daquele artefato, mesmo que a fala do papagaio estivesse na dependência relativa da voz humana. É assim que, por meio do "raciocínio lógico" do papagaio, a natureza valoriza-se por não necessitar de constantes intervenções do homem. M as, por outro lado, é em função da presença do fonógrafo que o papagaio é capaz de "formular" a sua lógica na concorrência com os demais animais, principalmente ante a al egada argúcia do macaco. O ra, o enfrentamento aí esboçado entre a natureza (o papagaio) e um dado artefato de cultura (o fonógrafo) é presidido por uma lógica de concorrência dentro da própria natureza, entre os bichos. 0 papagaio precisa precaver-se do macaco a fim de preservar o seu privilégio de continuar habitando a sala.

N esse seu primeiro romance, portanto, Abguar Bastos tendia a representar literariamente a Amazônia a partir de uma mistura de el ementos oriundos da mitologia e da natureza, mas em conexão com uma realidade social já marcada pela mecanização. A presença por si só do fonógrafo na sala determina, de certa forma, o comportamento dos demais bichos. Portanto, insinua-se no início do romance uma conclusão possível: não se trata de tomar a natureza como instância explicativa da realidade social, mas sim de utilizá-la como instrumento eficaz no desvelamento dessa mesma realidade e promover, ao fim, a sua transformação. $D$ aí o sentido da lógica e da argúcia entre os bichos.

M as a caracterização de Bepe como um "herói regional", e em tudo divergente do perfil picaresco de M acunaíma, também explicita a estraté gia adotada por Abguar Bastos nesse intrincado "jogo social" de conquista e consolidação de uma posição no campo literário. Eleger a realidade regional como tema prioritário de suas narrativas e, ao mesmo tempo, filiar-se a uma corrente literária empenhada de maneira quase militante na promoção de mudanças sociais converteram-se em lances decisivos para a sua conseqüente trajetória como escritor. 0 entrecho de Terra de icamiaba, portanto, não deve ser abstraído da lógica de funcionamento 
do próprio campo literário e dos anseios de seu autor em tornar-se um escritor reconhecido.

Após estudar e destacar-se como aluno brilhante em um seminário em Belém, o herói do romance desilude-se com a vida levada na cidade e principal mente com as diversas correntes literárias por ele então conhecidas. As aventuras e desventuras amorosas dos companheiros de Bepe na capital paraense - Reginaldo, o poeta lírico, e eremias, o poeta romântico - satirizam não só as posturas literárias passadistas, mas também convencem 0 herói da frivolidade do ambiente urbano:

Logicamente Bepe teria de escolher entre um lirismo estúpido e um romantismo decadente.

Culpa dos panoramas.

Entrou confiadamente n'alma de muitas mulheres.

Trouxe a sua parte no que Ihe convinha do aparato do corpo. Só!

D isse loucuras com juízo.

$\mathrm{N}$ ão desejou nem uma das almas exposta. Para quê?

D epois do Reginal do e do Jeremias teve medo do amor, na Cidade G rande.

Teve medo do ambiente.

As cigarras ainda estavam cantando, os sinos ainda estavam dobrando. E Bepenão quis o amor (Bastos, 1997, p. 29).

A opção de Bepe pelos mistérios da selva e sua recusa tanto do amor romântico (o amor puro) como do meio urbano conferem à sua personalidade uma caracterização peculiar: é o "gênio do lugar" dotado de senso de justiça, perspicácia e rigidez moral suficientes para o enfrentamento dos problemas e das injustiças que acometem os estratos sociais rebaixados da região. 0 s personagens estrangeiros que compõem o entrecho do romance, nesse sentido, são os al vos da ação vingativa de Bepe. $N$ a medida em que 0 judeu Calabar, o marroquino Amar e o holandês Lazaril são apresentados ao longo da trama como os vilões a espoliar a população do interior amazônico, em conluio com determinados políticos locais, a armação do romance ganha um desenho a separar dois pólos opostos: os bons contra os maus, os fracos contra os fortes. D o lado dos fracos, e arregimentados pelo herói, aparecem o caboclo M auro, o índio C olumbu e o negro Catulê. Bepe, por sua vez, por ter trilhado o caminho da cidade para a selva e por ter na sua geneal ogia ascendência nordestina e guarani, não só encarna em si essas três raças, como também parece desfrutar de uma "posição intermédia" entres 
esses pólos. M as essa posição intermediária não o isenta de tomar partido do "pólo fraco" diante do "pólo forte", liderando, assim, uma rebelião dos oprimidos no combate aos estrangeiros e exploradores.

Q uanto ao aspecto estritamente político do romance, não há dúvidas em relação à perspectiva deA bguar Bastos. A região amazônica não poderia continuar sendo explorada segundo os interesses estrangeiros em detrimento da população local. Seu nacionalismo militante era então expresso por um regionalismo quase empedernido. Já quanto ao aspecto literário, no entanto, o seu nacionalismo aparecia nessa obra exatamente no enfrentamento de personagens nacionais contra personagens estrangeiros, como, aliás, também ocorria em $M$ acunaíma. $M$ as, diferentemente deste último, lá tudo passa pelo filtro da região.

0 mosaico de mitos e lendas que compõe o romance é todo de origem local e articula-se em conformidade com uma real idade projetada pelas crenças políticas encampadas pelo autor. É nesse sentido que, no desfecho do romance, logo após a vitória da rebelião/revolução, Bepe, de posse de um muiraquitã a ele presenteado por um índio, lidera todo o contingente de revoltosos/revolucionários em uma peregrinação pelo interior da selva na busca da "terra das icamiabas". É de posse desse lendário amuleto que uma nova sociedade pode ser fundada no coração da Amazônia. U ma resolução literária, portanto, distinta daquela de $\mathrm{M}$ ário de Andrade, que, ao utilizar 0 muiraquitã como motivo de peregrinação de $M$ acunaíma pelo Brasil, pretendia fazer emergir a singularidade de uma realidade já existente. Abguar Bastos, inversamente, formula o seu romance com os ol hos voltados para a mudança, daí a utopia da "terra das icamiabas".

\section{Então Bepe olhou a multidão e falou para ela:}

- Eu nada quero para mim. A felicidade alheia faço-a minha e só ela é um conforto. Vamos vencer milhares de léguas; as rosas-dos-ventos girarão nos seus pontos cardeais, tantas vezes os nossos olhos as interroguem com aflição. Sei que muitos temores e dúvidas procurarão seduzir a confiança que está nestes corpos e nestas almas. Sei que o silêncio amadurecerá pensamentos importunos. $M$ as as surpresas não farão recuar os homens que me acompanham, porque sabem eles quão terrível é este labirinto de rios e florestas, onde a vida é improdutiva, o amor bárbaro, a piedade é falsa e o sorriso é inglório. O nde o homem se acaba, antes de compreender o colorido das coisas. O nde o trabal ho vibra sem recompensa, o dia se estagna sem curso e as vozes amolecem sem remédio, tal a vertigem da solidão. Tudo é farto, exuberante, alegórico mesmo. No entanto, todos os esforços são anônimos, 
todas as lutas são impessoais, todas as atribulações nascem e desaparecem, como relâmpagos na treva. Você, homem, derruba a cachoeira, fende o rio, torcea floresta, come a praga, bebe o veneno e quebra os cornos dos bichos ferozes. Vocêcarrega a família às costas e atravessa as torrentes; desarvora as palafitas e escora os barrancos; entra no peito dos repiquetes e espreme as caudais nos desfiladeiros; engole moléstias piores que o raio; desalaga os pântanos, devora com os passos andejos os caminhos apertados. O nde há um buraco você faz uma cidade. O nde há uma barreira de mato puro, amanhã é picada, depois é chão limpo, por onde a civilização vai passar. Você, homem, faz tudo isto. Contudo ninguém o conhece, você morre na miséria, sem teto e sem consolo. Você desanima, some-se e o seu nome fica perdido por aí, como os ventos. A terra é cada vez maior e mais bonita. O estrangeiro cada vez mais vai caçoando de você. O ra! Um dia, quando estas paragens mudarem de panorama e tudo for um alucinado esplendor, palavra, ninguém falará nos obscuros pioneiros que fizeram a obra gigantesca da exploração. Acordemos. Vamos para mais longe e façamos, nós mesmos, a nossa história (Bastos, 1997, pp. 165-166).

A despeito dos mistérios, dos labirintos edos perigos oferecidos pela floresta, éo trabalho eo esforço não reconhecido dos habitantes da região, em última instância, a ser valorizado por Bepe nesse seu discurso de convencimento para a busca e a construção de uma nova sociedade amazônica. A natureza não surge como uma espécie de empecilho maior para a implantação de qualquer projeto civilizador em plena selva. 0 s entraves são de ordem social, assentados na exploração e no esquecimento corriqueiro dessa população regional.

D iferentemente do último conto do livro de Alberto Rangel, Inferno verde, publicado em 1908, aqui não é a natureza que fecha a obra em um discurso eloqüente a vaticinar a impossibilidade de uma civilização na Amazônia. Bepeéo herói visionário a combater os poderosos e conhecedor dos segredos da floresta. Seu nome, retirado da mitologia indígena, o autoriza a construir um outro mundo. Se, por um lado, entre a obra de Alberto Rangel e a de Abguar Bastos, essa clara mudança de foco quanto aos eventuais fatores a criar algum tipo de empecilho para a consolidação de uma civilização na Amazônia revela a própria alteração na dinâmica a reger 0 campo de produção simbólica no Brasil, por outro lado o delineamento do herói da trama de Abguar Bastos demonstra o novo tipo de embate a ser travado no âmbito do campo intelectual eliterário. A oposição entre Bepe e M acunaíma reproduz no plano da criação romanesca as linhas de força 
que então permeavam os diferentes escritores desigualmente posicionados no interior desse espaço social peculiar que é o campo literário.

\section{Referências Bibliográficas}

ABREu, Alzira \& BELoCH, Isabel (coords.). (1984), D icionário biográfico brasileiro (19301983). Rio de Janeiro, Forense U niversitária/FGV/Finep.

ALm EID A, José M aurício G omes de. (1999), A tradição regi onalista no romance brasileiro (1857-1945). Rio de Janeiro, Topbooks.

Am Aral, Aracy. (1997), Blaise Cendrarsno Brasil eosmodernistas São Paulo, Editora 34. ANDRADE, M ário de. (1997), M acunaíma, o herói sem nenhum caráter. Belo H orizonte/Rio de Janeiro, Villa Rica.

AndRADE, 0 swald de. (1996), M anifesto da poesia pau-brasil, M anifesto antropófago \& 0 rei da vela. Rio de Janeiro, Paz eTerra.

Barbosa, Clovis. (2001), Equador. M anaus, Edições do Governo do Estado do Amazonas/Secretaria de Estado de Cultura, Turismo e D esporto.

Bastide, Roger. (1983), “M acunaíma em Paris”. In: Pereira de Q ueiroz, M aria I saura (org.), Roger Bastide. São Paulo, Ática, pp. 78-80.

Bastos, Abguar. (1937), Safra. Rio de Janeiro, José O lympio. . (1997), Terra deicamiaba; romance da Amazônia. M anaus, Editora da Universidade do Amazonas. . (2002), "Flami-n'-assú: manifesto aos intelectuais paraenses". Jornal da U BE, 100: 9 , out.

Bourdieu, Pierre. (1989), "A identidade e a representação; elementos para uma reflexão crítica sobre a idéia de região". In: . 0 poder simbólico. Tradução de

Fernando Tomaz. Lisboa/Rio de Janeiro, Bertrand/Difel, pp. 107-132. . (1996a), As regras da arte; gênese e estrutura do campo literário. Tradução de M aria Lúcia M achado. São Paulo, Companhia das Letras.

. (1996b), "Por uma ciência das obras". In: . Razões práticas; sobre a

teoria da ação. Tradução de M ariza Corrêa. Campinas, Papirus, pp. 53-73.

C Andid o, Antonio. (2000a), A educação pela noite\& outros ensaios. São Paulo, Ática. . (2000b), Literatura esociedade: estudos deteoria ehistória literária. São Paulo,

T. A. Q ueiroz.

Cavalheiro, Edgard. (1944), Testamento de uma geração. Porto Alegre, Globo.

Costa, Craveiro. (1940), A conquista do deserto ocidental. São Paulo, Companhia Editora Nacional.

FIGUEIREDO, Aldrin M oura de. (2001), Eternos modernos: uma história social da artee 
da literatura na Amazônia (1908-1929). Campinas, 315 p. Tese de doutorado. Instituto de Filosofia e Ciências H umanas da Universidade de C ampinas.

FreYre, Gilberto. (1943), Continenteeilha. Rio deJaneiro, C asa do EstudanteBrasileiro. . (1967). M anifesto regionalista. Recife, Instituto Joaquim N abuco de Pesquisas Sociais/MEC.

InojosA, Joaquim. (1975), "Visão geral do modernismo brasileiro". In: . Os

Andrades e outros aspectos do modernismo. Rio de Janeiro, Civilização Brasileira, pp. 240-284.

JURT, Joseph. (2004), "D e Lanson à teoria do campo literário”. Tempo Social, 1 (16): 29-54, jun., São Paulo.

Kотне, Flávio. (2004), 0 cânone republicano II. Braślia, Editora da UnB.

LAfetÁ, João Luiz. (2000), 1930: a crítica e o modernismo. São Paulo, D uas Cidades/ Editora 34.

Leite, Lígia C hiappini M oraes. (1994), “Velha praga? Regionalismo literário brasileiro". In: Pizarro, Ana (org.), América Latina, palavra, literatura e cultura. São Paulo, M emorial da América Latina/Editora da U nicamp, v. 2, pp. 665-702.

M ARTINs, W ilson. (1978), H istória da inteligência brasileira (1915-1933). São Paulo, Cultrix/Edusp, v. VI.

M enezes, Raimundo. (1978), Dicionário literário brasileiro. Rio de Janeiro, Livros Técnicos e Científicos.

M ICELI, Sérgio. (2001), Intelectuais à brasileira. São Paulo, C ompanhia das Letras. - (2004), "Experiência social e imaginário literário nos livros de estréia dos modernistas em São Paulo". Tempo Social, 1 (16): 167-207, jun., São Paulo.

N unes, Benedito. (1979), 0 swald Canibal. São Paulo, Perspectiva.

RANGEL, Alberto. (2001), Inferno verde: cenas e cenários do Amazonas. M anaus, Valer/ Governo do Estado do Amazonas.

Ribeiro, Gustavo Lins. (1993), M acunaíma: to be and not to be, that is the question. Brasília, U nB, no. 140, Série Antropológica.

Schaden, Egon. (1989), A mitologia heróica de tribos indígenas do Brasil. São Paulo, Edusp.

Sen A, N icodemos. (2002), "O arauto de boas-novas". Jornal da U BE, p. 9, out., São Paulo.

SousA, Gilda de M elo e. (1979), 0 tupi e o alaúde: uma interpretação de M acunaíma. São Paulo, Duas Cidades.

Velloso, M ônica. (1988), "A literatura como espelho da nação". Estudos H istóricos, 2 (1): 239-263, Rio de Janeiro.

- (1996), M odernismo no Rio de Janeiro: turunas e quixotes. Rio de Janeiro, Fundação Getúlio Vargas. 


\section{Resumo}

Um outro herói modernista

A partir da análise do romance de estréia de Abguar Bastos, Terra de icamiaba, o texto intenta demonstrar como a cisão do movimento modernista em diferentes vertentes estéticas e políticas foi apreendida por autores de regiões mais distantes dos centros culturais do país. Se o movimento de 1922 representou uma pretensa ruptura com o passadismo literário, ele acabou por converter-se em um momento decisivo para a formação de um campo literário no Brasil. 0 romance inaugural de Abguar Bastos ganha importância em função da sua divergência com M ário de Andrade quanto às temáticas da nacionalidade e do regionalismo, fazendo reverberar por outras regiões e cenáculos literários os debates acerca dos rumos do movimento.

Palavras-chave: C ampo literário; C riação literária; N acionalidade; Regionalismo.

\section{Abstract}

Another modernist hero

Based on the analysis of the debut novel by Abguar Bastos, Terra de icamiaba, this article attempts to show how the splitting of the modernist movement into different aesthetic and political tendencies was apprehended by authors from regions located far from the country's cultural centres. While the 1922 movement represented an attempted rupture with literary nostal gia, it ended up becoming a decisive moment in the formation of a literary field in Brazil. Abguar Bastos's first novel acquires importance here because of its divergence from $M$ ário de Andrade in relation to the themes of nationality and regionalism, allowing the debates over the movement's directions to reverberate in other regions and other literary circles.

Keywords: Literary Field; Literary C reation; N ationality/Regionalism.

Texto recebido em 8/ 2/2007 e aprovado em 20/3/2008.

M arco Aurélio Coelho de Paiva é professor do D epartamento deC iências Sociais da UniversidadeFederal do Amazonas. E-mail: macp40 @ufam.edu.br. 